First public review reveals dissenting voice

Dissent among the five research councils has for the first time marred the customary gentility of the annual recommendations by the Advisory Board for the Research Councils (ABRC) on the British science budget. In what is meant as fighting talk, the Agricultural Research Council (ARC) says it "cannot associate" itself with the proposal that its own budget should take a declining share of the funds available beginning in the financial year 1984-85.

Ironically, this row has surfaced on the first occasion when the board's advice to the Secretary of State for Education and Science (Sir Keith Joseph) has been published. Sir Alec Merrison, the board's chairman, says that the row is unprecedented. The recommendations now made are provisional in that they will have to run the gauntlet of the British government's annual expenditure review, now under way. Sir Keith Joseph, the minister, has, however, already lopped $£ 6$ million from the proposed budgets of the Social Science Research Council (SSRC), asking that this sum should instead be used for recruiting young scientists to university posts, and has quickly fallen in with the recommendation that the British Museum (Natural History) should not spend in excess of $£ 23$ million to extend its exhibition space at South Kensington.

The recommended budgets for ARC imply a constant contribution from the science budget of $£ 46$ million in each year for the three years beginning next April, implying that the council will have to make good the unknown consequences of inflation by internal economies.

This parsimony towards ARC (and to a lesser extent towards the Natural Environment Research Council (NERC)) stems from the board's view that funds within the science budget should be diverted to other better causes - an increase in real terms of the funds available to the Science and Engineering Research Council (SERC) to support initiatives in fields such as information technology and for the provision of posts for younger scientists now frozen out of the research system.

Merrison explained last week that ARC had been singled out because of the large proportion (just over a half) of its budget channelled through the agriculture ministry to support commissioned applied research and because its links with universities are weaker than those of the other research councils.

But ARC has not yet lost hope. At a

recent meeting the council endorsed the formal dissent of its secretary, Dr Ralph Riley, from the $\mathrm{ABRC}$ recommendations, and in the next few weeks will be asking Sir Keith Joseph to take a broader view of national priorities in general and ARC's research enterprise in particular. If more funds are not found, ARC reckons that it will have to lose 300 staff over the next three years, of whom 200 will be scientists, and that in 1984-85 it will be spending $£ 7$ million out of a total budget of $£ 107$ million to meet the cost of staff pensions and severance pay.

ABRC's argument is guided by its explicit choice of the fields in which publicly supported civil science should be encouraged: biology (especially biotechnology), remote sensing, information technology, marine resources

\title{
Harvard accused of impropriety
}

\section{Washington}

A government audit has concluded that Harvard Medical School improperly charged $\$ 1.7$ million to federal research grants from 1975 to 1977 and failed to document a further $\$ 29$ million charged during the same period.

The findings by the Department of Health and Human Services (HHS), which runs the National Institutes of Health and the Public Health Service, were the latest salvos in the battle that has been waged between Harvard and the government during the five-year federal investigation of Harvard's management of grants. Last year, an HHS audit of Harvard's School of Public Health found $\$ 2.1$ million in improper charges by the university.

Asked whether Harvard would repay the sums in question, the university's director of auditing, Anthony Woodworth, said, "I very much doubt it". He said both audits are the subject of negotiations with HHS officials, and that they merely represent "recommendations" to the government, not orders for repayment.

Woodworth said that an independent audit by the accounting firm of Coopers and Lybrand of Harvard's management of grants in fiscal year 1978 "gave us a clean bill of health". He suggested that HHS's release of their recent findings was a public relations stunt.

The HHS audit specifically claims that the medical school improperly transferred $\$ 1.6$ million in charges from one project to another to cover cost overruns and to ensure that all available grant money was spent. The auditors said that some $\$ 3$ million was charged without adcquatc documentation, and that the validity of $\$ 26$ million that went to pay salaries could not be verified because of poor records.

Harvard appears to be trying to suggest that the dispute is one of academic freedom and the neurosciences. But the board also says that its cutting of the cake this year reflects the view that the retreat from big science (experimental high-energy physics, space research) begun in the 1960 s has gone far enough, and its general concern for the well-being of research and researchers in universities.

Running through the board's statement is its theme-song for 1982 - that funds spent on civil science, in universities or elsewhere, should be directed with industrial needs in mind. Its report says that it has "readily agreed" to help carry out a study (jointly with the Advisory Council on Applied Research and Development) whose terms of reference apparently leave no room for consideration of the snags that such collaboration may encounter.

versus government meddling. Harvard and other universities have invoked academic freedom in resisting government efforts to require better accounting of how a faculty member divides his time between teaching and various research projects.

Harvard's attitude clearly annoys HHS. As one government official said, "What I find amazing is that we become the "bad guys' for trying to reclaim the taxpayers' money".

Dr Delphis Goldberg, of the House Government Operations Committee panel that oversees HHS, said that the audits

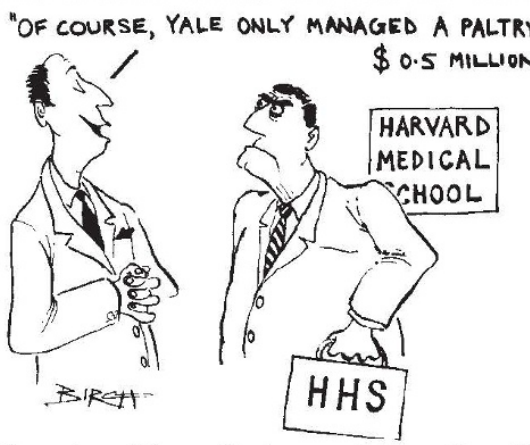

found problems that went deeper than the dispute over effort reporting by faculty. At the School of Public Health, he said, "there has been a substantial diversion of moneys" from specific grants to totally unrelated research projects, even projects under different principal investigators.

The investigation of Harvard grew largely out of charges by Dr Phin Cohen, formerly an assistant professor of nutrition at the School of Public Health. In 1976, he accused the school of diverting funds from his NIH grant to other unrelated projects. A subsequent NIH audit confirmed his accusations - Harvard was required to return $\$ 132,000$ - and recommended a full-scale audit of Harvard research grants by HHS. 